\title{
Hazy Agenda, Multiple Interests: Stakeholders Engagement with the First Phase of the Niger Delta Amnesty Deal in Nigeria
}

\author{
Isaac Olawale Albert \\ Institute for Peace and Strategic Studies, University of Ibadan, Ibadan, Oyo, Nigeria \\ Email: ioalbert2004@yahoo.com
}

How to cite this paper: Albert, I. O. (2019). Hazy Agenda, Multiple Interests: Stakeholders Engagement with the First Phase of the Niger Delta Amnesty Deal in Nigeria. Beijing Law Review, 10, 656-670. https://doi.org/10.4236/blr.2019.104037

Received: January 6, 2019

Accepted: July 27, 2019

Published: July 30, 2019

Copyright $\odot 2019$ by author(s) and Scientific Research Publishing Inc. This work is licensed under the Creative Commons Attribution International License (CC BY 4.0).

http://creativecommons.org/licenses/by/4.0/

\begin{abstract}
The oil-rich Niger Delta region of Nigeria is bedeviled by revolutionary violence. The grouse of the militant youths in the region is that their communities are degraded by oil prospecting activities of and also that they get too little from the federation allocations from the oil wealth controlled by the federal government. Unable to defeat the militants militarily, the federal government in 2009 adopted an amnesty programme that offered the fighters life sustaining opportunities for dropping their guns. The policy was implemented in two phases: 1) the militants drop their guns and without any negotiation or legal framework for admittance of specific guilt get automatic amnesty and 2) those granted amnesty get rehabilitated and reintegrated into the society. This paper is on how different stakeholders in the Niger Delta engaged with the initiative. The paper focuses on five major stakeholders: the federal government which owned the amnesty programme; the Niger Delta Governors who were required to co-facilitate the weapons recovery in their respective states; the warlords under which the Niger Delta militant youths were organized; the political godfathers in the Niger Delta with whom many of the militant groups had working relationship and; the community leaders into whose communities the ex-militants would return into. In the absence of any legal framework for their working relationship, each of the stakeholders acted so selfishly that the amnesty programme today lacks sustainability. While the federal government used the policy to relatively increase Nigeria's oil output, the others manipulated the process to oil their interests in winning the 2011 elections with the militants as key stakeholders. The amnesty programme divided the militants around selfish interests. Militancy is back to the region but not coordinated because the militants are now divided.
\end{abstract}

\section{Keywords}

Niger Delta, Oil, Militants, Amnesty Policy, Nigeria 


\section{Introduction}

There are five key stakeholders in the Niger Delta crisis: the militants, the oil companies they attack, the federal government, Niger Delta governments, Niger Delta elders, and the people of Niger Delta who suffered in the hands of law enforcement agencies as well as the militants marauding their communities. This paper takes a critical look at how three of these stakeholders namely, the federal government, Niger Delta governors, and the militants engaged with the amnesty policy of the government in 2009. This paper is written in a policy-relevant way that could inform future discussions on amnesty as post conflict peacebuilding in Nigeria. The position of the paper is that the Niger Delta amnesty policy lacked any clear focus. The goal was largely to coerce Niger Delta militants into dropping their guns for some pecuniary benefits without any concrete plans of engaging the problems faced by the Niger Delta people. Niger Delta Governors also engaged with the policy from their respective selfish points of view. At the end of it all, the militants dropped their guns. Oil companies benefit from this in terms of increased production. The people of the Niger Delta also experienced relative peace but the entire scenario was not one that could assure the different stakeholders in the Niger Delta crisis any sustainable peace.

The bulk of the data for writing this paper came from the basic ideas generated from my discussions with relevant stakeholders around the Niger Delta territory as the Board Chairman of the Society for Peace Studies and Practice (SPSP) from 2009 to 2017. I was also privileged to have interacted with several stakeholders on the issues of the amnesty programme as the Board Chair of Leadership Initiative for Transformation and Empowerment (LITE Africa) based in Warri (Niger Delta). I participated in Nigeria's 2014 National Conference held in Abuja and also served as a member of the Presidential Committee on the Review of Nigeria's Defence Policy in 2014 and 2015. In all of these engagements, I acquired substantial knowledge about the Niger Delta crisis. This shaped my literature search while writing this piece.

From a legal perspective, amnesty means to be "exemption from prosecution for criminal action. It signifies forgiveness and the forgetting of past actions" (The Columbia Encyclopedia, 2004). On the one hand, it connotes a state of power asymmetry in a conflict: one party won the war situation and the other lost. In this case, amnesty is packaged by the victorious side as part of its post conflict peace building strategies. Those benefits from such gestures include rebels, members of an overthrown regime, military deserters and other categories of people who stand the chance of being prosecuted for their past criminal actions (Damico, 1975: p. 23). On the other hand, the South African experience presents another functionality of amnesty. In this case, both sides to the conflict consider themselves to have hurt each other in the conflict process. To restore a healthy relationship both sides confessed what they did to each other, asked for forgiveness and were granted amnesty for such criminal acts. The Nigerian amnesty to be discussed in this paper is different from these two models on the 
ground that the federal government that introduced it did not attain any victory over the Niger Delta militants. In fact, the government introduced the amnesty largely because of the failure to defeat the militants militarily. On the other hand, the amnesty also did not issue from any process of negotiation between the Niger Delta militants and the government. The latter simply decreed it and used stick and carrot strategies to make the militants accept it.

The Niger Delta amnesty deal was implemented in two phases. Under the first, the militant youths were invited to submit the arms and ammunition in their possession for a blanket amnesty which freed them from any legal prosecution in addition to some being granted some life sustaining resources. Under the second phase, those militants that submitted their weapons are rehabilitated and reintegrated. The first phase of the project lasted officially from June 25, 2009 to October 4, 2009; they second phase which started since then is still going on. This paper has to do with this very first phase of the project. The particular focus of the paper is on how different stakeholders in the Niger Delta engaged with the initiative by either supporting or rejecting the amnesty initiative. The paper focuses on five major stakeholders: the federal government which initiated and managed the project; the Niger Delta Governors who were required to co-facilitate the weapons submission project in their respective states; the warlords under which the Niger Delta militant youths were organized; the political godfathers in the Niger Delta with whom many of the militant groups had working relationship and; community leaders in the Niger Delta who have critical roles to play in the reintegration of the ex-militants into their respective communities as the second phase of the project.

\section{The Amnesty Policy}

An amnesty deal stands between an obligation to prosecute and punish past crimes on the one hand and treat such matters with impunity on the other hand. The two extremes have problems in a transitional society. Punishment would translate into demonstrating that the state lacks the capacity to make some sacrifices for the sake of future peace and reconciliation at the end of a protracted conflict. Impunity, on the other hand, could be easily misinterpreted to be an evidence of a state's lack of capacity to ensure order by dexterously dealing with criminal acts. Hence, amnesty is based on the understanding that punishment would further aggravate the existing distrust between the conflict parties on the one hand but also that complete impunity would encourage a repetition of the same crimes in the future. In other words, amnesty forces perpetrators to regret their acts on the one hand and walk away from justice on the other hand. The most important variable in this case is that the beneficiary from an amnesty deal is only assured of respite for as long as he does not go back to the criminal act.

Generally speaking, amnesty is a post conflict peacebuilding strategy; it is considered to be an act of magnanimity from a post conflict state. If it has to truly play the role of post conflict peace building it has to be seen as a two-sided 
phenomenon in which both the state and the group that offended the state are treated as perpetrators that would require the amnesty deal. In most cases, state violence whether physical, psychological and structural creates many of the problems that led to the conflict that amnesty deals respond to. In the course of counter-insurgencies launched by states against rebel groups, it is a known fact that human rights of the rebels are equally violated. This was why the amnesty deal in South Africa involved both the whiles and blacks and not limited to the agents of the apartheid regimes alone. Within this framework, an amnesty makes meaning where both "rebel groups" and the state participate in the amnesty process with a view to building a new future (Walsh, 1996: p. 111).

The Niger Delta amnesty discussed in this paper borrows from the Truth and Reconciliation Commission of South Africa which was introduced in the 1990s to cement the relationship between the forces of the apartheid South Africa and the black population who took over political power in 1994. A second reading of the literature on the South African TRC calls attention to three major problems with the Nigerian project. The first is that in South Africa, amnesty was a post conflict building process that was preceded by a peacemaking process (negotiation between white and black South Africans) (Chubb \& dan Dijk, 2001; Graybill, 2002; Bois-Pedain, 2007). Both sides agreed that revisiting the past was necessary for promoting reconciliation and that granting of amnesty to perpetrators would allow the truth of what happened in the past to be known to all and sundry and where necessary reparation paid to deserving citizens and groups, The South African amnesty was granted after the transition to democracy in 1994. The conditional amnesty was an exceptional "rite of passage" into the new, post-conflict society. Perpetrators of violence from all conflicting parties were involved in the process which enabled them to fully disclose their "politically motivated crimes". Victims also had the opportunity of naming perpetrators and forcing the latter to acknowledge the past and ask for amnesty.

In the South African situation, the beneficiaries from the deal formally applied and each of them stated clearly the criminal acts for which they would like the state to grant them amnesty. This is meant to achieve three related objectives. It enables the truth to be known (what the perpetrators actually did as different from what they were said to have done). It enables those in charge of the amnesty to have sufficient facts for processing reparation which is a non-negligible component of the amnesty deal. Last but not the least, it enables those in charge of the post conflict Peacebuilding process to know the number and location of individuals and groups with whom the perpetrators would have to be reconciled.

The possibility of using amnesty for managing the Niger Delta crisis was first mentioned by the Technical Committee on the Niger Delta set up by the administration of President Umar Musa Yar'Adua in 2008 under the leadership of Barrister Ledum Mitee. In the report of the Committee submitted to the government in December 2008, it was recommended that revenue allocation from oil and gas should be increased to $25 \%$ (additional $12 \%$ ) to enable the region recover from obvious neglect of the past. It was recommended that within six months 
of the submission of the report, the government should commence a decommissioning, disarmament and reintegration (DDR) process aimed at stopping kidnapping, hostage taking and attack on oil installations in the Niger Delta. This should include a negotiated release of Henry Okah the leader of MEND and the granting of amnesty for deserving Niger Delta militants. The government was expected to improve the operational integrity of security forces and Police in the region; establish by 2010, regulations that compel oil companies to have insurance bonds against environmental pollution, strengthen independent regulation of oil pollution, and enforce critical environmental laws. The government was expected to fully resettle all displaced persons from Bakassi not later than December 2009 (MOSOP, 2008).

When the government of President Yar'Adua pronounced the Niger Delta amnesty policy 2009, the three elements of the project namely 1) the release of Henry Okah, 2) the granting of amnesty to militants and 3) the setting up of a DDR programme could be seen to have emanated from the Ledum Mitee report. But a number of other stakeholders claimed authorship of the project. At the ceremony where the militants in Bayelsa State formally surrendered their weapons at Isaac Boro Peace Park in Yenagoa on August 22, 2009 Governor Timipre Sylva claimed to have mooted the idea of the amnesty to the Federal Government (Olaniyi, 2009: p. 13). Rivers State Government claimed to have originated the programme. However, the focus of this paper is not really on the ownership of the project but how different stakeholders engaged it.

\section{Federal Government's Carrot and Stick}

In attaining the objectives of the amnesy programme, the federal government of Nigeria adopted what could be characterized as a carrot and stick strategy. In this case, "carrot" refers to a friendly approach to managing a problem while the "stick" refers to the use of force. Hence, the carrot and stick approach alluded to in this paper has to do with a combination of the coercive and non-coercive methods of attaining a security objective. In practice, amnesty is a non-coercive policy. By this is meant that a criminal is forgiven his/her offences and allowed to walk away from justice believing that this approach is more rewarding than adopting a punitive approach to dealing with the matter. Normally, those who have committed heinous crimes against the state ask for amnesty. But it could also be dangled at those the government would not want to continue to fight. In both cases, it is expected that the offences for which amnesty is being granted would be formally document for future references.

What happened in the Niger Delta is that though the federal government saw being granted the amnesty as those who have committed some crimes against Nigeria and Nigerians, the approach adopted in dealing with them was to grant all of them a blanket amnesty: you sign and then your sins are forgiven. While some militants signed unto the programme immediately, some refused to sign. What the government did was to start threatening the latter with military attacks now that those who have signed have started giving out some of their operation- 
al secrets. That is the "stick" aspect of the policy. The situation is better explained in the discussions that follow.

The first line of engagement that should be noted here is how the federal government that started the programme engaged with it. The then Minister of Defence, Major General Godwin Osagie Abbe (rtd) defined amnesty in the peculiar Nigerian context as "a legislative or executive act by which State restores those who may have been guilty of offences against it to the position of innocence" (Abbe, 2009: p. 72). He provided two legal frameworks for the policy. The first has to do with Section 175 of the Nigerian Constitution which granted the President to grant pardon to any person concerned with or convicted of any offence. The General argued that this section of the law enables the President of Nigeria to grant reprieve to anybody and this was the legal framework for the amnesty programme. He observed that the President also held a consultative meeting with the Governors of the Niger Delta region on June 16, 2009 on the decision of the government to grant the militants amnesty. On June 25, 2009 the President also met the Council of State as provided in the Constitution. Given the support of the Niger Delta Governors and the Council of State, the President made a nationwide broadcast on June 25 during which he proclaimed the amnesty policy which took effect on August 6 and ended on October 4, 2009.

The amnesty was proclaimed on June 24, 2009 by President Umar Yar'Adua but the 60 day project took off on August 6, 2009 and it was expected to end on October 4, 2009. In the speech delivered at the inauguration of the deal, President Yar'Adua observed that any militant that fails to take advantage of this opportunity would face the full weight of the law. This position has been reiterated by many of the security officers associated with the implementation of the deal. For example when some militants surrendered their arms and ammunition at Okrika, Rivers State, on August 202009 the Assistant Inspector-General of Police for Zone 6 observed that any militant that fails to submit his weapons before the October 4 deadline "will be on their own" (Olaniyi, 2009: p. 13). The coordinator of the Amnesty Implementation Committee, Air Vice Masrashall ... and the Media Coordinator to the Committee used the same language in a paid documentary aired on AIT television on August 31, 2009.

The Presidential Implementation Committee is chaired by the Minister of Defence, Major General Abbe (rtd). The project is directly coordinated and supervised by Air Vice Marshal Lucky Ararile while the Media aspect of the project is handled by Agary. The project has four aspects-DDRR. Both PTDF and the Niger Delta Ministry would provide skills training centre for retraining the militants. The deal which was managed from the office of the Director of Operations at the Defence Headquarters in Abuja provided for "unconditional amnesty and unconditional pardon for all persons who have directly or indirectly participated in militant struggles or the commission of offences in the course of militant activities in the Niger Delta”. The amnesty process is very simple: “... go to the nearest screening centre, turn in their arms, register, take the oath of renunciation and receive the presidential amnesty and unconditional pardon". Thereaf- 
ter, the former militant is registered for the reintegration programmes" (Ajaero, 2009: p. 29).

As the federal government worked on the amnesty, it also seemed to have started working on war strategy. The position of the federal government is that whichever of the militants that failed to surrender his arms would be forced to do so by military means after the October 4 deadline. There were several indications to this effect. Interviewees from the Niger Delta called our attention to new "recent developments". The first is that JTF operatives started to fortify their positions by bringing in more sandbags to the various checkpoints they created round the Niger Delta. The number of the checkpoints also increased. The people also claimed to see on regular basis trailers carrying gunboats across the communities. The frequency within which the interviewees claimed to have seen such trailers suggest that it was probably same set of vehicles that were being moved round the communities in what could have been a process of psychological warfare aimed at intimidating the militants to surrender their arms. Some Niger Delta youth also claimed to have seen some soldiers mounting devices for electronic (most especially telephone) signals in their communities.

The second indication was in an article written by Daniel Volman, the Director of the African Security Research Project in Washington DC written for the South Africa-based news agency, Inter Press Service (IPS) but reproduced by Tell Magazine of September 28, 2009. Volman observed that as the militants were disarming, the federal government was busy "buying hundreds of millions of dollars worth of sophisticated weaponry and military hardware in preparation for a new offensive in the Niger Delta" (Volman, 2009: p. 37). The arsenals include two 24.8-metre Shaldag MK-2 patrol boats worth $\$ 25$ million from an Israeli company, Israel Shipyards. This type of boat is usually armed with artillery guns and machine guns. The government is also said to have paid for air and sea drones from Aeronautical Ventures, another Israeli company. The same company and the Israel's Aeronautics Defence Systems also supplied to Nigeria a surveillance system for the Niger Delta that uses unmanned drones. This is in addition to eighty Nigerian sailors being sent on counter-insurgency operations training at the northern Israeli port of Haifa.

In anticipation of the future counter-insurgency operations in the Niger Delta, Nigeria acquired 20 troop-carrying catamarans from a Dutch firm, TP Marine, for transporting soldiers up the creeks and across small rivers of the Delta. The fighting powers of the Nigerian navy was also boosted with weapons and ships acquired from Malaysia, Singapore. The Nigerian Air Force was also provided with at least $15 \mathrm{Mi}-24, \mathrm{Mi}-34$ and $\mathrm{Mi}-35$ helicopter gunships and troop transport helicopters armed with Gatling guns, machine guns, bombs, rocket launchers and rockets from Russia. Russian instructors were brought down to Nigeria to train Nigerian pilots on how to use these helicopters. In addition to all these, there was also the orchestrated report that the government was strengthening the structures for counterterrorism in the region through the training of more police officers (Albert, 2009). 


\section{Niger Delta Governors}

The project was meant for five Niger Delta States (Ondo, Delta, Bayelsa, Rivers and Akwa Ibom) but only three of them were probably most important to the federal government: Delta, Bayelsa and Rivers where the problem of youth militancy were at its highest. At the initial stage, all of them signified their readiness to support the deal. However, the Petroleum Industry Bill that the Federal Government placed before the National Assembly at about the same time that the amnesty issue was being discussed provided the opportunity for the Governors to grandstand against the federal government on the amnesty. The bill, as alleged by Niger Delta Governors, aimed to relocate the Petroleum University at Effurun, Delta State to Kaduna in Northern Nigeria. The university when relocated was to get a grant of N14.5 billion. On the other hand, the Governors said the government wanted to downgrade the Petroleum Training Institute (PTI) in the Niger Delta to a low and middle cadre training institution. The governors consider this to be a continuation of the issues that led to youth militancy in the Niger Delta region and threatened to withdraw their support for the amnesty policy except the vexed issues were redressed.

President Yar'Adua met the South-South Governors in mid August 2009 to sort out the issues. He assured the governors that his decision to upgrade the PTI in Effurun to a university was taken by his predecessor, Chief Olusegun Obasanjo and that he had no intention to transfer the institution to Kaduna as alleged. The meeting enabled the Governors to extract from the federal government an agreement to incorporate the payment of royalties to the oil producing communities in the Petroleum Industry Bill (Ajaero, 2009: p. 27). After this, the governors rescinded their threat to jettison the amnesty deal and have been since then working for the success of the project.

However, there were other issues to be addressed. Though initiative by the Federal Government Niger Delta governors were expected to own and facilitate the amnesty programme in their respective states by encouraging the militants to come out and be part of the deal. Each of the governors engaged the amnesty deal opportunistically thereafter. The release of Okar and the refusal of a section of MEND to embrace the amnesty broke the militants into two opposition camp: those in support and those against the policy. Those in support were motivated and coordinated by state governors who sought to use the opportunity to establish themselves as being in control of the militants and by so doing preparing themselve for the 2011 elections in their respective states. For example following the release of Okah, Governor Sylva of Bayelsa led some militants to Abuja. The largest haul of weapons submission in the amnesty deal took place on August 22, 2009 in Yenogoa, Bayelsa State when sixteen militant groups operating in the creeks turned in 14 gunboats, 520 assorted rifles (AK 47, K2, LAR, MG and G3), 95,970 rounds of live ammunition and 41 full military fatigues to agents of the amnesty committee. Fourteen of the groups came from Bayelsa State and the remaining two from Rivers State. Present at the occasion were General Owei 
Africa, Commander Ogunbos, Commander Lagos, Commander Lamin, Osein Clever and Agulu Opuoru (said to be the second in command to Kitikata) (Ajibola, 2009a: p. 6; Olaniyi, 2009: p. 13). The surrendered weapons were received by trhe Chairman of the Presidential Amnesty Implementation Committee, AVM Lucky Ararile in company of the AIG Zone 5, Julian Okpaleke and the Bayelsa Chairman of the Niger Delta Peace and Conflict Resolution Committee, Chief James Jephthah.

Sylva too was severally accused of paying Boyloaf N250million to facilitate his acceptance of the amnesty offer. The attempt to deny this allegation also implicated the role of godfathers in the amnesty deal. Speaking through his Chief Press Secretary, CPS Doife Ola, Governor Sylva blamed the rumour on his detractors whose interest was to discredit him in order to get nominated for the 2011 gubernatorial election in Bayelsa State. Showing very well that the Governor knew the person behind the rumour, he noted "... the government of Bayelsa State would not have bothered about the hot air from this fellow, who thinks ruling Bayelsa state, is his birthright, and whose stock in trade is pulling down every government in the state-from Diepreye Alamieyeseigha to Sylva ... Sylva hereby states that he never gave money to Boyloaf or any militant to accept the president's amnesty" (Onyekwere, 2009: p. 20).

The allegation that Boyloaf was paid for the Abuja visit to Yar'Adua and the subsequent surrender of arms re-echoed on September 4, 2009 when some of the militants that accompanied Boyloaf for the exercise went on rampage in Yenogoa on the allegation that their allowances were not paid by the government. They threatened to return to the creeks if the government did not make good the promise made to pay each of them N10million for laying down their arms. They claimed that the government was owing each of them the sum of N600,000 as allowances for three months by the time they staged the protest. As their spokesperson, one Ozuikwu Katsina, claimed "They promised us N10miilion each when we came out of the creeks to enable yes take care of our families and learn handiworks, but we have seen nothing". One of the boys belonging to Boyloaf camp too noted that "Since what we expected from them has not happened, the peace process won't be realistic ... if our money is not given to us we have to resume our restive activities". They claimed that the government only gave attention to Boyloaf and the other big boys (Joshua Maciver and Ogunbus) who were housed in Government House Yenogoa while the others were hardly cared for (Ombe, 2009: p. 5). They asked the government to make good its promise within 24 hours otherwise they would return to the creeks. They accused their leaders of colluding with the Baylesa State government of diverting the allowances meant for the militants. They threatened to attach the policemen and operatives in charge of their camps if the conditions of the camps were not improved (Etim, 2009: p. 1 and 49).

Failure to get positive response from the government, the boys once again jumped to the streets of Yenogoa on September 11, 2009 asking for the allowances to be paid. They disrupted movement of vehicles in Biogbolo, Yeni- 
zue-Gene, Kpansia and Ekeki areas forcing motorists from avoiding these parts of the Bayelsa State capital. The intervention of SSS and officials of the Bayelsa $\mathrm{CR}$ prevented the militants from clashing with operatives of JTF. However, then of them were arrested and detained by the police. The Secretary to the Niger Delta CR blamed the "opposition" for the problem. His position was that those against the government encouraged the militants to stage the protests. The chairman of the organization, Jephtar claimed that it was not the responsibility of his organization to address issues relating to logistics and payments to the militants. Its own role was limited to ensuring that the militants surrendered their weapons (Oduma, 2009). But Agari looked at the matter from a different perspective. She presented the militants as agents of those who want to give the government a bad name and not real militants. She claimed that those who are true militants are supposed to have gone to any of the four registration centres for documentation after which they are paid and readied for rehabilitation. What her statement was calling attention to was that it was the responsibility of Bayelsa state government to cater for those outside the official camps (Niger Delta Standard 2009).

About 200 "ex-militants" for the third time in one month went on rampage on September 252009 in Yenogoa protesting non-payment of their allowances. They barricaded the only road leading to the city at Akenfa and in the process paralyzed social and economic activities in Yenogoa while the protest lasted. As earlier done, they asked for the allowances and accused the government of only taking care of the big militants forgetting their followers. The government responded to the situation by beefing up the security of the city (Ajibola, 2009b: p. 6).

In Rivers State, the government was more interested in the implementation of its own amnesty package started much earlier than that of the federal government. Despite his official claims to the contrary, it is believed that the Governor of Rivers State is not disposed to the amnesty deal of the Federal Government. Several factors are responsible for this. The first and probably the most important is that Governor Amaechi has a zero-tolerance for the militants who failed to surrender their arms when he invited them to do so early in the year. He was therefore averse to going out to beg the same militants he had threatened with military actions in the past.

The River States government was also probably not too confident in the ultimate objectives of the federal government amnesty deal given the ways the government handled the past dealings with the militants in the region. His hide-and-seek stance, according to Comrade Success Jack, President of the Niger Delta Activist Forum, a special militant representative of three notorious groups in Rivers State (George, Sobomabo Jackris and Commander Ebi Egbiri), is said to have "a tinge of political interest" which for now is difficult to understand (Onyekwere, 2009: p. 19).

The third reason why the Rivers State government was not too excited about the federal amnesty can be deduced from a statement credited to the Chairman of the Rivers State Government's Social Rehabilitation Committee (SRC), Chief 
Albert Horsfall, a former Director General of the State Security Service (SSS) and a former Chairman of the defunct Oil Mineral Producing Areas Development Commission (OMPADEC). He claimed that what is now packaged as the amnesty deal by the Federal Government is the blueprint for rehabilitating repentant militants in Rivers State (Olaniyi, 2009: p. 13). In other words, it makes more sense to give attention to the Rivers State amnesty than the federal one as both are aimed at rehabilitating the militants.

Horsfall claimed that by September 9, 2009, the Social Development Institute (SDI) built by Rivers State Government at Okehi, headquarters of Etche Local Government Area of Rivers State would have graduated 297 ex-militants who were trained for six months in various trades. Each of the graduates would be provided with loans. The training provided the ex-militants is not only skills-based but also attitudinal changing. They were given new orientations that would enable them to become better members of a decent society as different from their past lives that centred on criminal violence. Horsfall claimed that the second batch of 600 trainees will commence their own training in October 2009 (Olaniyi, 2009: p. 13). The impression that he was simply creating was that the amnesty package of the Federal Government was nothing to compare with that of Rivers State in terms of age and programming.

Amaechi's lack of excitement about the presidential amnesty deal forced members of the committee to do more legwork in Rivers State than the other Niger Delta states. The work of the committee at the initial stage focused largely on counteracting the rumour that Governor Amaechi was planning to use the amnesty deal to arrest the militants that dared to come out of hiding. The militants were also torn between politicians putting them under pressure to and not to accept the amnesty (Onyekwere, 2009: p. 18). Therefore several confidence-building meetings had to be organized with representatives of the militants by security agencies. Most of the meetings took place few weeks in July and August 2009. Those at the most crucial of the meetings held in Port Harcourt which preceded the Abuja meeting that President Yar'Adua was Barrister Ikenna Enekweizu representing Ateke Tom, Innocent Iboroma for Dagogo, Pastor Success Jack for George and Cletus Arerebo represented Boyloaf as well as Osama Bin Laden. On the government side were Mike Okiro, the Inspector General of Police, General Godwin Abbe, the Minister of Defence and chairman of the Amnesty, the Rivers State Commissioner of Police and Director of SSS. It was to assure the militants that none of them would be arrested should they come out. At the end of the meeting the representatives of the militants held a press conference during which they offered to support the presidential amnesty (Onyekwere, 2009: p. 18).

The militants that later surrendered their arms in Rivers State following this meeting include Soboma George, Solomon Ndigbera (Osama Bin Laden), Wisdom Amachree (General Adekunle), Nwogu Justice Chisom (General JayJay) and the people of Kula community in Akuku-Toru Local Government area of Rivers State. The Akuku-Toru situation was interesting. On August 22, 2009 
they surrendered 42 rifles (consisting of $14 \mathrm{AK} 47$, one AK49, five general purpose machine guns, $12 \mathrm{G} 3$, one rocket propelled grenade, six FN rifles, one smoke gun); 371 rounds of ammunition and 14 dynamites. This was the first time a community, rather than individual militants, surrendered arms. Yet the community was not known to have had any history of militancy as generally understood in the Niger Delta. While submitting the weapons in Port Harcourt, the elders of the community said they acquired the weapons to prosecute an intra-communal conflict (Amaize, Onah, \& Oyadongha, 2009: p. 36).

As early as July 27, 2007 the government of Bayelsa State had established a unit known Niger Delta Peace and Conflict Resolution Committee (NDPCRC) which was saddled with the responsibility of liaising with militant groups in the state and security agencies with a review to restoring peace to the Niger Delta. Unlike the experience in Rivers State where the government engaged with the amnesty deal cautiously, the government of Bayelsa through NDPCRC, led by the Chairman, Chief James Jephthah, combed the creeks and militant camps to convince the boys to embrace the amnesty (Lartey, 2009: p. 50). At the end of it all, Governor Sylva found a willing partner in Boyloaf, one of the militants represented at the Port Harcourt meeting who later became the official face of the amnesty as he offered to meet President Yar'Adua in Abuja.

Delta state is believed to harbor the strongest militant leaders in the Niger Delta, including Tompolo. Yet, the militants in Delta State were not seriously committed to the amnesty project. The success of the project in the state can be assessed from two perspectives: 1) the readiness of Tom Polo which was behind the May 2009 "creek war" to be part of the project and 2) the willingness of the other militants in the state to surrender their arms and ammunition. The government focused its attention on getting Tompolo to be part of the project. Several emissaries were sent to him. On the other hand, the other militants were not treated with any serious regards as reflected in the following.

\section{Data Discussion}

On the other hand, the Niger Delta amnesty deal was imposed on the Niger Delta people by the federal government without any concrete negotiation or mediation process that could have clearly articulated the other key components of the peace process which the amnesty deal was supporting. The amnesty deal was based on the belief that if the Niger Delta militants committed any offence at all, it was against the Federal Government which was prevented from having free access to the oil resources in the Niger Delta. The reason for this is that the Nigerian amnesty deal did not follow the best global practices of empowering victims: most especially the Niger Delta communities that are devastated by oil exploration and destroyed in the course of the several military operations that took place in the Niger Delta region. In the other parts of the world, the victims (and not only the Federal Government in this case) were granted the permission of coming out to define what the perpetrators did against them. The amnesty captured these. Inability to do this in Nigeria made it impossible for the interests of 
many people who had to pay millions of Naira to the militants in order to have their kidnapped family members free were not taken into consideration. The conditions of legitimate oil business companies who have their staff kidnapped and their oil products stolen away seemed not to have been taken into consideration. What various Niger Delta communities suffered as a result of the violent military operations between the militants and the JTF was not taken into consideration.

A situation where only the non-state actors are forced to go through the amnesty process creates future problems. In this case, those expected to benefit from the process might consider it to be a sign of defeat rather than an act of reconciliation with the other party. Even when defeated, groups with strong political values and demands would rather continue the struggle clandestinely until when captured and completely eliminated or escape abroad on exile than accept amnesty which is considered to be humiliating and subversive to the course of the group. However, such a people would appreciate state pardon in a process of incarceration as they may have no alternative means of getting freedom outside such a gesture.

The implementation of the deal suggests clearly that the federal government was not too sure about the militants that were expected to benefit from the deal. Hence, by 2012 young people from the Niger Delta are still coming out to say they were former militants left out of the largesse of the amnesty project. However, the amnesty project enabled many of the big names in the Niger Delta youth militancy to come out and embrace the amnesty. Sixteen of these militant leaders were invited to the post-amnesty meeting called by President Umar Yar'Adua on Friday, October 9 2009. The most notable among them were High Chief Government Ekpemepolo (a.ka. Tompolo) from Delta State, Chief Ateke Tom from Rivers State, and Ebikabowei Ben (a.k.a Boyloaf) from Bayelsa State. The others are Franklin Duduku (Cross River), Bonny Gawei (Delta), Africa Ukparafa (Bayelsa), Farah Dagogo (Rivers), Soboma George (Rivers), Erefimudei Olotu (Bayelsa), Ezekiel Akpabewei (Delta), Kenneth Dan Opsingi (Rivers), Bibopre Ajube (Ondo), Henry Egbema (Edo), Solomon Indigbana (Rivers), and Key Kile Torugwedi (Bayelsa) (Ikuomola, 2009: p. 4). Absent from the meeting were Okah who was not in the country and Dokubo who said he would have nothing to do with the amnesty deal.

The project was bedeviled by too many selfish interests. Whereas the interests of the Federal Government was to use the deal to clear the Niger Delta of the militant youths in order to protect the oil industry in the region, the politicians who engaged with the process as governors, advisers and community leaders manipulated the process to fit into their political ambitions in the 2011 elections. The militants too engaged with the deal not as a group but individuals with various selfish interests.

\section{Conclusion}

The point made by this paper is that the 2009 amnesty programme in the Niger 
Delta region of Nigeria is a child of necessity. The government adopted the policy having realized it would take a long time to militarily defeat the Niger Delta militants. But many things were wrong with the programme. The amnesty programme was a blanket one. It lacks any legal framework in which the offence for which the "ex-militants" were granted was named. Did the militants commit any offence? They would answer this question in the negative while the government would say the ex-militants were granted amnesty for taking up arms against the Nigerian state. On the other hand, the militants would merely see themselves as freedom fighters. Many of them are today back to the creeks where they engage in different forms of violent activities. If they are arrested today, of what value is the amnesty they got in 2009 ?

The second problem is that the federal government did not seem to have had any roadmap for the policy that clearly differentiates between the roles of the different stakeholders. All that the federal government wanted was for the militants to stop attacking oil installations to enable Nigeria's oil revenue to increase. What the federal government wanted was simply for the state government to participate in the process by helping to beg the militants in their jurisdictions to accept the amnesty programme. But the governors had their own issues, too. They would not do anything that would hurt their ambition to be re-elected during the 2011 elections. Hence, they used the resources provided them by the federal government to campaign for the support of the militants. Those militants that would have nothing to do with the federal governments were not forced to do so by any governor. Some of the governors also used the policy to get some concessions from the federal government. Totally left out of the project was the leadership of the communities into which the militants were expected to return after their rehabilitation. Some of the militants are today back to violent activities in the Niger Delta largely because Nigerian leaders could not harmonize their interests around the amnesty project.

\section{Conflicts of Interest}

The author declares no conflicts of interest regarding the publication of this paper.

\section{References}

Abbe, G. O. (2009). Amnesty: The Journey So Far. The Guardian, November 8, 72.

Ajibola, S. (2009a). Amnesty: Militants Surrender 2 Gunboats, 200 Guns. Saturday Tribune, August 22, 6 .

Ajibola, S. (2009b). Militants on the Rampage. Saturday Tribune, 26 September, 6.

Albert, I. O. (2009). Towards an Actionable Early Warning and Response System for the Niger Delta. In I. O. Albert (Ed.), Praxis of Political Concepts and Clichés in Nigeria's Fourth Republic (pp. 393-406). Ibadan: Bookcraft.

Amaize, E., Onah, G., \& Oyadongha, S. (2009). Amnesty and Militants Arms Surrender: How Far? Sunday Vanguard, September 30, 36-37.

Bois-Pedain, A. D. (2007). Transition Amnesty in South Africa. Cambridge: Cambridge 
University Press. https://doi.org/10.1017/CBO9780511495120

Chubb, K., \& dan Dijk, L. (2001). Between Anger and Hope: South Africa's Youth and the Truth and Reconciliation Commission. Johannesburg: Witwatersrand University Press.

Damico, A. J. (1975). Democracy and the Case for Amnesty. Gainesville, FL: Florida Presses.

Etim, W. (2009). Repentant Militants Threaten Return to the Creeks. The Guardian, September 5,1 and 49 .

Graybill, L. S. (2002). Truth and Reconciliation in South Africa: Miracle or Model? Boulder, CO: Lynne Rienner Publishers.

Ikuomola, V. (2009). Amnesty: Yar'Adua, N/Delta Governors, Ex-Militants Keep Mum. The Nation, October 10, 4.

Lartey, O. (2009). Niger Delta: Politics of Amnesty, Disarmament. Saturday Punch, September 5,50 .

MOSOP (2008). Recommendations of the Technical Committee on the Niger Delta. Port Harcourt: Movement for the Survival of the Ogoni People.

Oduma, I. (2009). Amnesty: Militant Leader Wants Military out. Niger Delta Standard, August 14, 1-2.

Olaniyi, B. (2009). Politics of Arms' Submission by Militants. The Nation, August 31, 13.

Ombe, I. (2009). Militants in Massive Protest over Unpaid Allowances in Yenogoa. The Nation, Sept. 5, 5.

The Columbia Encyclopedia (2004). The Columbia Encyclopedia (6th ed.). New York: Columbia University Press.

Volman, D. (2009). Government Gears up for Another Offensive in the Niger Delta. Tell, September 28, 37.

Walsh, B. (1996). Resolving the Human Rights Violations of a Previous Regime. Journal Title: World Affairs, 158, 111.

Onyekwere, J. (2009). Divided They Stand. The Week, August 24, 16-23.

Ajaero, C. (2009). A New Deal on Niger Delta. Newswatch, August 17, 26-29. 